\title{
Corrigendum
}

\section{Interview with the New Head of the Library of the Max Planck Institute for Comparative and International Private Law - correction}

\author{
Claudia Holland and Liz Murray
}

https://doi.org/I0.1017/SI472669618000506, Published by Cambridge University Press, I February 2019.

In the recent article Interview with the New Head of the Library of the Max Planck Institute for Comparative and International Private Law we did not have all the necessary consents to use the original Figure 3, which has been replaced with a generic image of the library. We apologise to the staff affected and to the readers of the journal.

\section{Reference}

Holland, C., \& Murray, L. (2018). Interview with the New Head of the Library of the Max Planck Institute for Comparative and International Private Law. Legal Information Management, 18(4), 246-25I. doi:10.10I7/SI4726696I8000506 